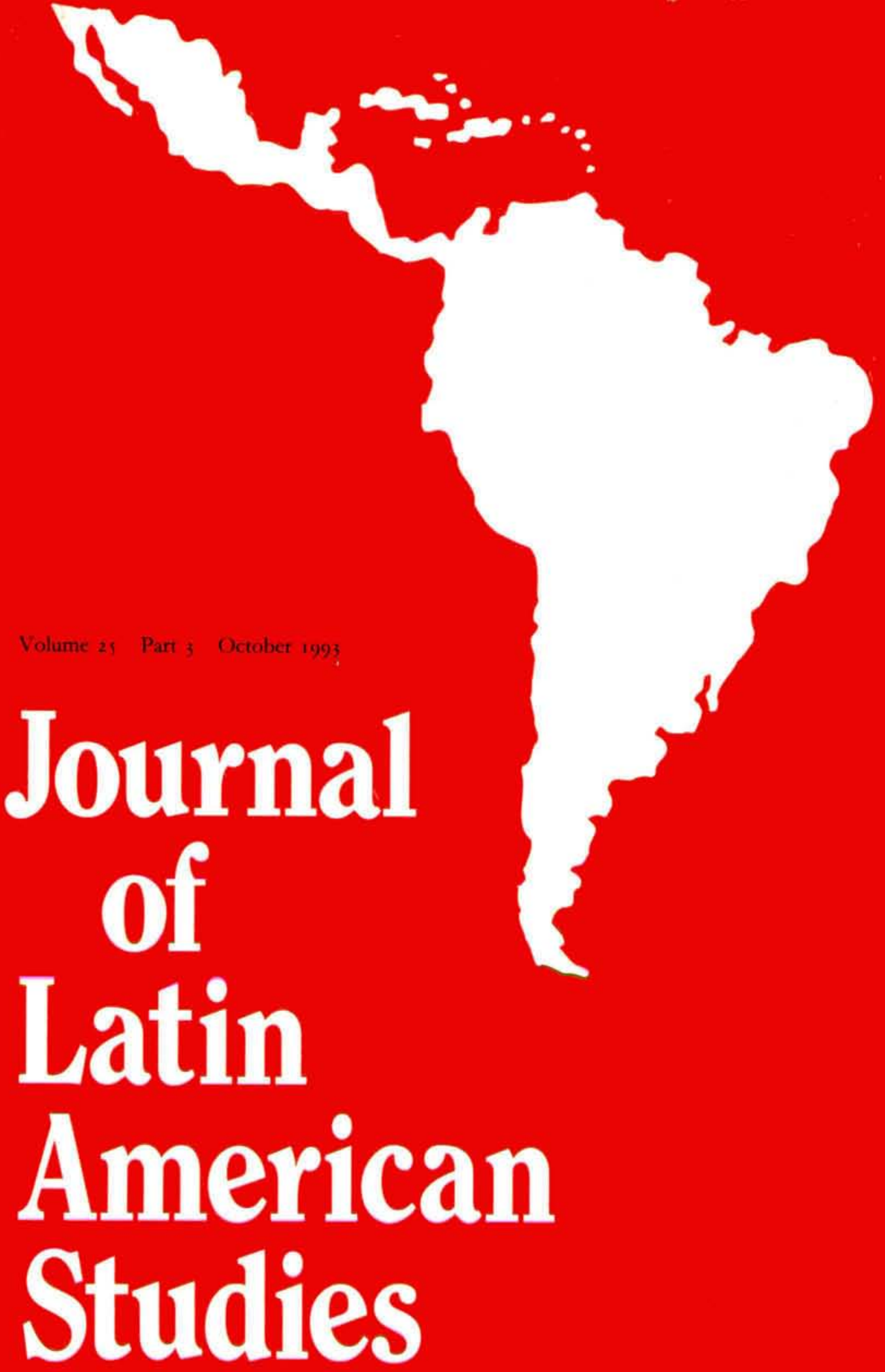

Cambridge Uiniversity Press 
EDITORIAL BOARD

Christian Anglade

University of Essex

David Brading

University of Cambridge

Victor Bulmer-Thomas

Institute of Latin American Studies, University of London

John Dickenson

University of Liverpool

James Dunkerley

Queen Mary and Westfield College, University of London

John Fisher

University of Liverpool
Peter Flynn

University of Glasgow

Olivia Harris

Goldsmiths' College, University of London

Alan Knight

St Antony's College, Oxford

David Lehmann

University of Cambridge

Sarah Radcliffe

Royal Holloway, University of London

Laurence Whitehead

Nuffeld College, Oxford

\section{INTERNATIONAL ADVISORY BOARD}

Giorgio Alberti

Università degli Studi, Bologna

Raymond Buvé

University of Leiden

Eliana Cardoso

Tufts University

Tulio Halperín Donghi

University of Califomia, Berkeley

Soledad Loaeza

Colegio de México

José Alvaro Moisés

Universidade de São Paulo, Brazil

Guillermo O'Donnell

Kellogg Institute, University of Notre Dame and CEBRAP, São Paulo
José Antonio Ocampo

Fedesarrollo, Bogotá

Luis Ortega

Universidad de Santiago, Chile

Alain Rouquié

Fondation Nationale des Sciences Politiques, Paris

Lars Schoultz

University of North Carolina

Henryk Szlajfer

Polish Academy of Sciences

Edelberto Torres-Rivas

FLACSO, San José, Costa Rica

Emilia Viotti da Costa

Yale University

\section{ASSISTANT EDITOR}

A. Bell

Institute of Latin American Studies, University of London

(C) Cambridge University Press 1993

\section{SUBSCRIPTIONS}

Joumal of Latin American Studies (ISSN $0022-216 \mathrm{X}$ ) is published three times a year in February, May and October. Single parts are $f_{1} 19.00$ net in UK (US $\$ 38.00$ in USA, Canada and Mexico) plus postage. Three parts form a volume. The subscription price (which includes postage) of volume 25, which also includes a cumulative ten year index, is $£ 71.00$ (US $\$ 124.00$ in the USA, Canada and Mexico) for institutions; $£_{37.00}$ (US $\$ 56.00$ ) for individuals ordering direct from the publishers and certifying that the journal is for their personal use. Special rates are available for students. Orders, which must be accompanied by payment, may be sent to a bookseller or to the publishers: Cambridge University Press, The Edinburgh Building, Shaftesbury Road, Cambridge CB2 2RU, and, in the USA, Canada and Mexico, The Journals Department, 40 West 2oth Street, New York, NY IOOII-42II. Japanese prices for institutions (including ASP delivery) are available from Kinokuniya Company Ltd, P.O. Box 55, Chitose, Tokyo.

\section{ADVERTISING}

Enquiries about advertising in this journal should be sent to the publishers. 


\section{Journal of Latin American Studies}

VOLUME 25 PART 3 OCTOBER 1993

EDITORS

VICTOR BULMER-THOMAS

Professor of Economics, Institute of Latin American Studies, University of London

LAURENCE WHITEHEAD

Official Fellow in Politics, Nuffeld College, Oxford 


\section{Contents}

\section{ARTICLES}

The Politics of Disease Control: Yellow Fever and Race in Nineteenth Century Rio de Janeiro

SIDNEY CHALHOUB

Politics and Elections in Buenos Aires, $1890-1898$ : The Performance of the Radical Party

PAUIA ALONSO

Not Quite British: A Study of External Influences on the Argentine Navy VARUN SAHNI

Labour and the War-Time Alliance in Costa Rica: 1943-1948 EUGENE MILLER

Foreign Policy Options Under Dependence: A Theoretical Evaluation with Evidence from Ecuador

JEANNE A. K. HEY

Elections, Political Parties and Political Culture in Brazil: Changes and

Continuities

JOSÉ ALVARO MOISÉS

Social Welfare Policy and Political Opening in Mexico

PETER M. WARD

\section{COMMENTARY}

'Are These Not Also Men?' The Indians' Humanity and Capacity for Spanish Civilisation

PATRICIA SEED

\section{REVIEWS}

Robert Haskett, Indigenous Rulers: An Etbnohistory of Town Government in Colonial Cuernavaca and

D. S. Chandler, Social Assistance and Bureaucratic Politics: The Montepios of Colonial Mexico, $I 767-182 I$, reviewed by Eric Van Young

Kevin Gosner, Soldiers of the Virgin: The Moral Economy of a Colonial Maya Rebellion, reviewed by Linda A. Newson

Desmond Gregory, Brute New World: The Rediscovery of Latin America in the Early Nineteenth Century, reviewed by Jason Wilson

Peter Blanchard, Slavery and Abolition in Early Republican Peru, reviewed by Michael J. Gonzales 
Manuel de Paz, Wangiemert y Cuba Vol. I and II, reviewed by Louis A. Pérez

Antón Pazos, La Iglesia en la América del IV Centenario, reviewed by John Lynch

Samuel Z. Stone, The Heritage of the Conquistadors: Ruling Classes in Central America from the Conquest to the Sandinistas, reviewed by Carlos M. Vilas

Marta Casaus Arzú, Guatemala: Linaje y Racismo, reviewed by Carlos M. Vilas

Albert Hourani and Nadim Shehadi (eds.), The Lebanese in the World: A Century of Emigration, reviewed by Jorge $\mathrm{O}$. Bestene

Antônio Lavareda, A Democracia nas Urnas: O Processo Partidário Eleitoral Brasileiro, reviewed by Paul Cammack

Emir Sader and Ken Silverstein, Without Fear of Being Happy: Lula, The Workers Party and Brazil, reviewed by Paul Cammack

Deborah Poole and Gerardo Rénique, Peru: Time of Fear, reviewed by Lewis Taylor

Alain Rouquié, Guerres et paix en Amérique Centrale, reviewed by Edelberto Torres-Riva

Breny Cuenca, El poder intangible: La AID y el estado salvadoreño en los años ochenta, reviewed by Rachel Sieder

Ivon Le Bot: La Guerre en Terre Maya: Communauté, violence et modernité au Guatemala, reviewed by J. P. Pérez Sáinz

Luis Humberto Guzmán, Politicos en Uniforme: Un balance del poder del EPS, reviewed by Carlos M. Vilas

John M. Kirk, Politics and the Catbolic Church in Nicaragua, reviewed by Laura Nuzzi O'Shaughnessy

Victor J. Elias, Sources of Growth: A Study of Seven Latin American Economies, revicwed by David E. Hojman

John H. Welch, Capital Markets in the Development Process: The Case of Brazil, reviewed by Tomás Bruginski de Paula

João Carlos Ferraz, Howard Rush and Ian Miles, Development Technology and Flexibility. Brazil faces the industrial divide, reviewed by John Humphrey

David E. Hojman (ed.), Change in the Chilean Countryside: From Pinochet to Aylwin and Beyond, reviewed by Walter Belik

Nora Lustig, Mexico: The Remaking of an Economy, reviewed by E. V. K. FitzGerald

Van R. Whiting, Jr., The Political Economy of Foreign Investment in Mexico: Nationalism, Liberalism, and Constraints on Choice, reviewed by Sylvia Maxfield

George J. Borjas and Richard B. Freeman (eds.), Immigration and the Work Force: Esonomic Consequences for the United States and Source Areas, reviewed by Jim Thomas

Juan M. Ossio Acuña, Parentesco, Reciprocidad y Jerarquia en los Andes: Una aproximación a la organización sacial de la comunidad de Andamarca, reviewed by Penny Dransart

Antonius C. G. M. Robben, Sons of the Sea Goddess: Economic Practice and Discursive Conflict in Brazil, reviewed by Paul Cammack

Kent H. Redford and Christine Padoch (eds.), Conservation of Neotropical Forests: Working from Traditional Resource Use, reviewed by Mahesh Rangarajan

Jaime Malamud-Gotti, Smoke and Mirrors: The Paradox of the Drug Wars, reviewed by Kevin Healy

Fredrick B. Pike, The United States and Latin America: Myths and Stereotypes of Civilization and Nature

and

Howard J. Wiarda, American Foreign Policy Toward Latin America in the 8os and gos: Issues and Controversies from Reagan to Bush, reviewed by Gordon Connell-Smith

Jonathan Hartlyn, Lars Schoultz, and Augusto Varas (eds.), The United States and Latin America in the rggos: Beyond the Cold War, reviewed by David Ryan

William Rowe and Vivian Schelling, Memory and Modernity: Popular Culture in Latin America, reviewed by David Lehmann

Glen Caudill Dealy, The Latin Americans: Spirit and Ethos, reviewed by S. L. Andreski

Francine Masiello, Between Civilization and Barbarism: Women, Nation and Literary Culture in Modern Argentina, reviewed by Verity Smith

Roberto Schwarz, Misplaced Ideas: Essays on Brazilian Culture, reviewed by T. F. Earle 